\title{
Neurokognitív zavarok diagnosztizálási és kezelési lehetőségei Parkinson-kórban
}

\author{
Lucza Tivadar dr..$^{1^{*}}$ - Karádi Kázmér dr. ${ }^{1^{*}}$ - Komoly Sámuel dr. ${ }^{2}$ \\ Janszky József dr. ${ }^{2,3}$ - Kállai János dr. ${ }^{1}$ - Makkos Attila dr. ${ }^{2}$ \\ Kovács Márton dr. ${ }^{2}$ - Weintraut Rita dr. ${ }^{1}$ - Deli Gabriella dr. ${ }^{2}$ \\ Aschermann Zsuzsanna dr. ${ }^{2}$. Kovács Norbert dr. ${ }^{2,3}$
}

\author{
Pécsi Tudományegyetem, Általános Orvostudományi Kar, ${ }^{1}$ Magatartástudományi Intézet \\ ${ }^{2}$ Neurológiai Klinika, Pécs \\ ${ }^{3}$ MTA-PTE Klinikai Idegtudományi Képalkotó Kutatócsoport, Pécs
}

A jelen tudományos közleményt a szerzők a Pécsi Tudományegyetem alapitásának 650. évfordulójának szentelik.

\begin{abstract}
Az összefoglaló közleményben a szerzők részletesen bemutatják a Parkinson-kórhoz társuló neurokognitív zavarok jellegzetességeit, felmérésük lehetséges módjait és kezelési lehetőségeit. A neurokognitív zavarok meghatározását sokáig nehezítette a diagnosztikai kritériumrendszerek sokszínúsége. Az Amerikai Pszichiátriai Társaság által a Mentális Rendellenességek Kórmeghatározó és Statisztikai Kézikönyvének ötödik átdolgozása (Diagnostic and Statistical Manual of Mental Disorders, DSM-5) magával hozta a major és az enyhe neurokognitív zavar megnevezéseket a demencia és az enyhe kognitív zavar fogalmát helyettesítendően. A DSM-5 neurokognitív zavarra vonatkozó definíciói a klinikumban jól alkalmazhatóak, ám szükségessé vált a leggyakrabban használt szűrőtesztek, úgymint a MiniMentál Státus Vizsgálat, az Addenbrooke Kognitív Vizsgálat, a Montreal Kognitív Felmérés és a Mattis Demencia Pontozó Skála új kritériumrendszerhez való adaptálása. Magyar Parkinson-kóros populáción végzett validálási vizsgálatok alapján a minor neurokognitív zavarra vonatkozóan a legjobb diszkriminációs képességgel rendelkező határértékek az iskolázottság mértékétől függően változnak (Addenbrooke Kognitív Vizsgálat: 0-8 év iskolázottság esetén: 82,5, 9-12 év esetén: 83,5, $\geq 13$ év esetén: 84,5 pont; Mini-Mentál Státus Vizsgálat: 26,5-27,5-28,5 pont; Montreal Kognitív Felmérés: 23,5-24,5-24,5 pont; Mattis Demencia Pontozó Skála: 138,5-139,5-139,5 pont). Orv. Hetil., 2015, 156(23), 915-926.
\end{abstract}

Kulcsszavak: Parkinson-kór, demencia, enyhe kognitív zavar, neurokognitív zavar, szűrés

\section{Neurocognitive disorders in Parkinson's disease}

In the present review the recent developments in the definitions of neurocognitive disorders associated with Parkinson's disease are summarized including the possibilities for screening and treating. For a long time, the recognition of neurocognitive disorders associated in patients with Parkinson's disease was unsatisfactory due to the heterogeneity of definitions. The recently developed Diagnostic and Statistical Manual of Mental Disorders, 5 th edition (DSM-5) introduced the definitions of mild and major neurocognitive disorders instead of mild cognitive impairment and dementia. The new DSM-5 definitions are clinically well applicable; therefore, the validation of the most frequent screening tests (Mini-Mental State Examination; Addenbrooke's Cognitive Examination; Montreal Cognitive Assessment; Mattis Dementia Rating Scale) is warranted. Based on a Hungarian sample of 295 patients with Parkinson's disease, the cut-off scores having the best discriminative values are highly dependent on education years (Addenbrooke's Cognitive Examination: 0-8 years of education: 82.5 points, 9-12 years of education: 83.5 points, and $\geq 13$ years of education: 84.5 points; Mini-Mental State Examination: 26.5-27.5-28.5 points, Montreal Cognitive Assessment: 23.5-24.5-24.5 points, Mattis Dementia Rating Scale: 138.5-139.5-139.5 points, respectively).

Keywords: Parkinson's disease, dementia, mild cognitive impairment, screening, neurocognitive disorder

Lucza, T., Karádi, K., Komoly, S., Janszky, J., Kállai, J., Makkos, A., Kovács, M., Weintraut, R., Deli, G., Aschermann, Zs., Kovács, N. [Neurocognitive disorders in Parkinson's disease]. Orv. Hetil., 2015, 156(23), 915-926.

(Beérkezett: 2015. február 27.; elfogadva: 2015. április 5.)

*Megosztott első szerzőség. 


\section{Rövidítések}

$\mathrm{ACE}=$ (Addenbrooke's Cognitive Examination $)$ Addenbrooke Kognitív Vizsgálat; DSM = (Diagnostic and Statistical Manual of Mental Disorders) Mentális Rendellenességek Kórmeghatározó és Statisztikai Kézikönyve; $\mathrm{MCI}=($ mild cognitive impairment) enyhe kognitív zavar; MDRS = (Mattis Dementia Rating Scale) Mattis Demencia Pontozó Skála; MDS = Movement Disorder Society; MMSE $=$ (Mini-Mental State Examination $)$ Mini-Mentál Státus Vizsgálat; MoCA $=($ Montreal Cognitive Assessment) Montreal Kognitív Felmérés; PD $=$ (Parkinson's disease) Parkinson-kór; PDD = Parkinson-kórhoz társuló demencia

A Parkinson-kór (Parkinson's disease - PD) egy neurodegeneratív betegség, amelyet a motoros tünetek mellett (bradykinesia, rigiditás, nyugalmi tremor) számos nem motoros tünet is jellemez. Alvászavar, depresszió, szorongás, kóros mértékü fáradékonyság jelentik a leggyakoribb nem motoros tüneteket, amelyek nagymértékben befolyásolják a betegek életminőségét [1] és szociális jóllétét [2]. Az újabb vizsgálatok eredményei alapján a nem motoros tünetek életminőségre gyakorolt hatása bizonyos esetekben akár jelentősen meghaladhatja a motoros tünetekét [2].

\section{Parkinson-kórban észlelhető neurokognitív eltérések}

James Parkinson 1817-es tanulmányában a kórt olyan betegségként írta le, amelyre csak a végstádiumban jellemző a kognitív képességek hanyatlása. Azonban bizonyos kognitív területek már a betegség kezdeti fázisában is érintettek lehetnek, ugyanis kezdeti stádiumban akár a betegek egyharmadánál is megfigyelhetô bizonyos károsodások jelenléte $[3,4]$.

A kognitív funkcióromlás leggyakrabban a végrehajtó funkciókhoz köthető teljesítményben figyelhetô meg, amely viselkedésgátlási, figyelemfenntartási és -váltási nehézségben nyilvánulnak meg $[3,4]$. A kognitív teljesítmény romlása, a motiváció csökkenése, a mozgástervezési, az összehangolási és a végrehajtási nehézségek a praefrontalis kéreg sérülésére utalhatnak, ám az ilyen tünetek jelenléte Parkinson-kórban kevésbé kérgi károsodással, mintsem a praefrontalis körök múködészavarával magyarázhatók [5]. A nigrostriatalis pályarendszer dopaminerg neuronjainak pusztulása mellett a kolinerg, a szerotoninerg és a noradrenerg rendszer károsodása is kimutatható, ami magyarázatot adhat arra, hogy az affektív és motivációs problémák mellett a kognitív múködés zavara is megjelenhet $[5,6]$. A frontostriatalis pályarendszer sérülésének köszönhetően jelentkező praefrontalis károsodás egyik következménye a diszexekutív szindróma [7]. Diszexekutív zavar Parkinson-kórban gyakran már a betegség korai stádiumában jelentkezhet, és a kogníció olyan területeit is károsíthatja, mint a komplex figyelem, a munkamemória, a viselkedéstervezés, a feladatváltás folyamata [7]. Szintén gyakran találkozhatunk a verbális fluenciát, illetve a vizuális és téri memóriát érintő eltérésekkel, amelyek megjelenése és súlyossága összefügg a Parkinson-kór aszimmetriájával [8].

A fiatalkorban kialakuló PD esetében gyakrabban forrul elő depresszió, illetve a betegségtartam növekedésével párhuzamosan demencia. A betegségtartam, a rigid-akinetikus altípus, a motoros tünetek súlyossága, a korán megjelenő hallucinációk lehetséges rizikófaktoroknak tekinthetők a PD-demencia megjelenéséhez [4]. Longitudinális vizsgálatok alapján felmerül annak a lehetősége is, hogy a kognitív érintettség és a demencia a betegség progressziójával párhuzamosan minden hosszú kórtörténettel rendelkező betegnél megjelenhet $[9,10$, 11]. A demencia előfordulása Parkinson-kórban 20-40\% [12], míg az egészséges személyekhez viszonyítva akár hatszor nagyobb is lehet [13].

A Parkinson-kórban fellépő kognitív funkciózavar vizsgálatát klinikai szempontból megnehezíti, hogy a „normális” és a „kóros” mértékű funkciózavar között nem éles az átmenet, a kognitív teljesítményromlást értékelő klinikai definíciók meglehetősen heterogének [14], illetve nem áll rendelkezésünkre olyan szúrőeszköz, amely közel százszázalékos specificitással és szenzitivitással rendelkezne.

A demencia és a „normális” kognitív teljesítmény közötti átmenetet az enyhe kognitív zavar (mild cognitive impairment - MCI) testesíti meg. Az MCI úgy is tekinthető, mint a normális öregedés és a demencia közötti kognitív állapot. Az újonnan diagnosztizált Parkinsonkóros betegek esetében az enyhe kognitív zavar (PD-MCI) kialakulásának valószínúsége kétszer nagyobb a normális idős személyekhez képest, valamint a betegség diagnosztizálását követő 3-5 évben a betegek 2057\%-ánál figyelhetố meg [15].

A PD-MCI tehát a demenciánál enyhébb, de az exekutív zavarnál súlyosabb kognitív károsodásként jellemezhető [6]. A károsodott kognitív funkciók tekintetében az enyhe kognitív zavar különböző altípusait különböztethetjük meg [16]: epizodikus memóriadiszfunkció (például szófelidézés), exekutív diszfunkció (például munkamemóriát, verbális fluenciát, kognitív kontrollt és tervezést igénylő feladatok megoldásának romlása), vagy több területet érintő diszfunkció (memória, végrehajtó funkciók és/vagy nyelvi készségek). Az átlagpopulációhoz mérve, amelyben az amnesztikus MCI-forma előfordulása a leggyakoribb, az újonnan diagnosztizált Parkinson-kóros betegek esetében a nonamnesztikus variánsok megléte a jellemzőbb [6]. A kognitív hanyatlás a betegség időtartamának előrehaladtával egyre gyakoribbá válik, azonban a progresszió sebességének mértékében nagy egyéni különbségek figyelhetôk meg [15].

Az enyhe kognitív zavar azonosítása alapján elöre jelezhető a későbbiekben kialakuló Parkinson-kórhoz tár- 
suló demencia. Ezen neurokognitív adatok birtokában például pontosabban ítélhető meg a mély agyi stimulátor beültetésének indikációja [17].

\section{Változó definíciók a neurokognitív zavarok diagnosztikájában}

Diagnosztika szempontjából a neurokognitív zavar súlyosságának pontos meghatározását nehezíti a definíciók heterogenitása. A neurokognitív zavar diagnosztizálásának alapvető lépései a beteg mentális állapotának felmérése, a lehetséges okok, illetve a társuló tünetek tisztázása, valamint a tüneteket súlyosbító okok (motoros vagy szenzoros érintettség, metabolikus zavar, vitaminhiány) felderítése.

A diagnózis felállításához egyaránt szükséges a beteg vagy a megfelelő információval rendelkező hozzátartozó véleménye a neurokognitív zavar meglétét illetően és a kognitív teljesítmény károsodásának standardizált neuropszichológiai tesztekkel (vagy ennek hiányában más kvantifikált klinikai mérőeszközzel) történő objektív felmérése. A két diagnosztikai lépés együttes vizsgálata a diagnózis még pontosabb megerősítését szolgálja. Ugyanis magasan iskolázott betegek esetében előfordulhat, hogy a neuropszichológiai teszteken „még normális" eredmény mutatható akkor is, amikor a kiindulási állapothoz mérten már határozott romlás észlelhető. Ezzel szemben egy alacsony intellektusú beteg esetében a teszteken mutatott "gyengébb" teljesítmény bizonyos esetekben csak a kiindulási alacsony értéket mutatja és nem feltétlenül jelez neurokognitív zavart.

\section{A DSM-IV-TR diagnosztikai rendszere}

$\mathrm{Az}$ Amerikai Pszichiátriai Társaság által kiadott és gondozott Mentális Rendellenességek Kórmeghatározó és Statisztikai Kézikönyve (Diagnostic and Statistical Manual of Mental Disorders - DSM) egyik fó feladata, hogy segítséget nyújtson a mentális tünetek osztályozásában. A DSM 4. verzióját 1994-ben adták ki, amelyet 2000ben részlegesen átdolgoztak (DSM-IV-TR, text revision) [18].

\section{Demencia fogalma a DSM-IV-TR szerint}

A DSM-IV-TR szerint demencia az alábbi szempontok alapján diagnosztizálható:

- Többszörös kognitív deficit kifejlődése, amit jellemez az alábbi kettő:

- Memóriazavar (új dolgok megtanulásának vagy korábban megtanult információk visszahívásának csökkent képessége).

- Az alábbi lebenytünetek legalább egyike: afázia, apraxia, agnosia vagy a végrehajtási (exekutív) funkciók zavara.

- Az előbbiekben jelzett kognitív deficitek mindegyike a szociális vagy foglalkozási múködésben jelentős káro- sodást okoz és az adaptív múködés korábbi szintjének jelentős hanyatlásában nyilvánul meg.

- A lefolyást lépcsőzetes jelentkezés és folyamatos hanyatlás jellemzi.

- Az előbbiekben jelzett kognitív deficitek nem magyarázhatók egyéb etiológiával (például cerebrovascularis betegség, hypothyreoidismus, $\mathrm{B}_{12}$-vitamin-hiány, folsavhiány vagy pszichoaktív szer okozta állapotok).

- Nem kizárólag delírium alatt jelentkezik a kognitív zavar.

- Nem magyarázható jobban más I. tengelyen jelzett pszichiátriai kórképpel (például depresszióval).

Amennyiben egy PD-beteg esetében a demenciakritériumok teljesülnek, úgy a PD-hez társuló demencia vélelmezhető. Azonban a Parkinson-kórhoz társuló neurokognitív zavarok nem minden esetben merítik ki a DSM-IV-TR demenciára vonatkozó definícióját.

\section{Enyhe kognitív zavar (DSM-IV-TR)}

A DSM-IV-TR függelékében kísérleti jelleggel meghatározásra került egy úgynevezett enyhe kognitív zavar (mild cognitive impairment - MCI) kritériumrendszer is. A DSM-IV-TR szerinti enyhe kognitív zavar esetében a kognitív tevékenységek romlása a „normális” mértéket meghaladja, de még nem teljesíti a demencia kritériumát. Az MCI fogalmát fóleg a klinikai kutatások számára dolgozták ki, ezért nem a fó diagnosztikai részben, hanem „csak” a függelékben kapott helyet.

- Legalább két héten keresztül fennálló, az alábbi kognitív funkciók közül legalább kettőben (vagy többen) bekövetkező károsodása, amelyet vagy a beteg, vagy egy megbízható információforrás jelez.

- Memóriakárosodás, amelyet az új dolgok megtanulásának vagy korábban megtanult információk viszszahívásának csökkent képessége jellemez.

- Végrehajtó funkciók károsodása (például megtervezés, elgondolás, sorrendbe állítás).

- Figyelem vagy az információfeldolgozás sebességének károsodása.

- Perceptomotoros képességek károsodása.

- Nyelvi képességek károsodása.

- Fizikális vizsgálat vagy labor-, képalkotó vizsgálatok objektív eltérései, amelyek a kognitív zavar etiológiájára utalhatnak.

- Neuropszichológiai tesztek vagy kóros mértékú, vagy pedig a korábbi állapothoz képest rosszabb teljesítményt igazolnak.

- A kognitív deficitek a szociális, a foglalkozási vagy pedig az egyéb tevékenységek területén jelentős károsodást okoznak és a korábbi képességek szintjének jelentős hanyatlásában nyilvánulnak meg.

- Demencia, delírium vagy egyéb amnesztikus zavar diagnózisa nem állítható fel és nem magyarázható jobban más pszichiátriai kórképpel (például depresszióval) sem. 
A fenti definícióból látható, hogy az MCI több altípusa is megkülönböztethető az érintett kognitív funkciók alapján: amnesztikus (főleg a memória területét érintő) és nem amnesztikus MCI, illetve egy területet érintő és több területet érintő MCI. Mivel az MCI esetén a betegek egy részénél évekkel késóbb demencia jelenhet meg, ezért gyakran az MCI-t a demencia „előszobájának” tartották. Az „amnesztikus” MCI általában Alzheimer-kórra utaló demencia, míg a nem amnesztikus MCI esetében általában egyéb típusú demenciaforma kiindulási állapotának tartható.

\section{Movement Disorders Society Task Force-kritériumok}

A Parkinson-kórhoz társuló demencia meghatározására sokféle diagnosztikai kritériumrendszer létezik. Talán ennek a változatosságnak tudhatók be az epidemiológiai kutatások egymásnak ellentmondó eredményei [19]. A diagnosztikai pontosság fokozása érdekében a nemzetközi Movement Disorder Society (MDS) kidolgozott egy kritériumrendszert [20]. Az MDS a PD-hez társuló demencia (PD-dementia - PDD) [19] fogalma mellett meghatározta az enyhe kognitív zavar Parkinson-kórban (PD-MCI) definícióját is [21].

\section{Demencia Parkinson-kórban (PDD, MDS-kritériu- mok)}

I. Alapvető kritériumok

- Queen Square Agybank-kritériumok szerint a PD klinikai diagnózisa felállítható.

- Demenciaszindróma, amely lappangó kezdetű és lassú progressziót mutat, a PD mellett alakul ki, és ami az anamnesztikus, a fizikai vizsgálat és a neuropszichológiai vizsgálat alapján diagnosztizálható.

- Legalább egy kognitív tartomány károsodása kimutatható.

- A korábbi premorbid állapothoz képest romlást jelent.

- A deficit eléggé súlyos ahhoz, hogy a beteg mindennapi életvitelét rontsa (szociális, foglalkozási vagy személyes tevékenységek), és független a motoros vagy az autonóm tünetek okozta korlátozottságtól.

II. Társult tünetek

- Kognitív tünetek: Károsodás a figyelem, a végrehajtó funkciók, a visuospacialis funkciók, a memória vagy a nyelvi készségek tekintetében (egy vagy több terület is érintett lehet).

- Magatartászavar (apátia, személyiségzavar, hangulatzavar, szorongás, hallucinációk, delúziók, kóros mértékű nappali aluszékonyság).

III. Tünetek, amelyek a PDD diagnózist nem zárják ki, de a diagnózist valószinütlenné teszik

- Más, önmagában is kognitív érintettséget okozó betegség, ami azonban a klinikus megítélése alapján nem a demencia oka (például képalkotó vizsgálaton észlelt vascularis encephalopathia).
- A PD motoros tünetei és a kognitív zavar közötti időviszonyok nem ismertek.

IV. Tünetek, amelyek más etiológiára utalnak vagy pedig a PDD diagnózisának felállitását lehetetlenitik el

- A kognitív és magatartászavar kizárólagosan egyéb okkal összefüggésben jelenik meg (például szisztémás betegség, intoxikáció, DSM szerinti depresszió).

- Valószínű vascularis demencia kritériumainak teljesülése esetén.

A PDD klinikai diagnózisa kétszintú. Mivel a biztos PD diagnózis csak szövettani eredményen alapul, ezért klinikailag (in vivo) csak a valószínú és a lehetséges PDD diagnosztizálható.

Valószinü PDD-rôl akkor beszélhetünk, ha mindkettő alapvető kritérium teljesül, legalább két kognitív terület érintett, miközben a III-as és a IV-es tünetek közül egyik sem észlelhető. Típusosan legalább egy magatartászavar kimutatható, azonban a magatartászavar tüneteinek hiánya önmagában nem zárja ki a valószínú PDD diagnózisát.

Lehetséges PDD esetében mindkettő alapvető kritériumnak teljesülni kell, de vagy atípusos kognitív tüneti károsodás észlelhető (például afázia vagy amnesztikus zavar dominálja a képet), vagy pedig egy III-as tünet észlelhető. Lehetséges PDD esetében sem szabad egyetlen IV-es tünetnek sem teljesülnie.

A diagnosztika két szinten történhet [20]. Az első szintű (Level I) diagnózishoz felállított kritériumok PDD esetében a következők lehetnek:

- Diagnosztizált Parkinson-kór a Queen Square Agybank kritériumai alapján.

- A Parkinson-kór a demencia megléte előtt kialakult.

- Mini-Mentál Státus Vizsgálaton elért kevesebb, mint 26-os pontérték.

- A kognitív deficitek súlyossága a mindennapi életvitelt is megnehezíti.

- Az alábbi tesztek közül legalább kettőn elért alacsony pontszám:

- Mini-Mentál Státus Vizsgálaton az ötszögrajzolás károsodott.

- Mini-Mentál Státus Vizsgálaton a „Világ” szó viszszafelé betűzése, vagy a százból hetesével visszaszámolás károsodott.

- Mini-Mentál Státus Vizsgálaton a három szó felidézése nem megfelelő.

- A betúfluencia vagy az órarajz károsodott.

A diagnózis második szintjét (Level II) a részletes neuropszichológiai tesztbatériákkal történő kognitív állapotfelmérés jelenti abban az esetben, ha az első szintú kritériumok alapján nem lehet egyértelmúen eldönteni a demencia esetleges fennállását, vagy pedig ha a PDD diagnózisa egyértelmú, de a kognitív profil klinikai vagy kutatási szempontból érdekes. Vizsgálatok alapján az MDS-kritériumok által felállított PDD diagnózisa a DSM-IV-TR demenciakritériumához képest sokkal szenzitívebb és specifikusabb is egyben [22]. 
Enyhe kognitív zavar Parkinson-kórban (PD-MCI, MDS-kritériumok)

\section{Alapvetö kritériumok}

- Queen Square Agybank-kritériumok szerint a PD klinikai diagnózisa felállítható.

- A PD lassú progressziót mutató kognitív zavar, amelyet vagy a beteg, vagy egy megbízható információval szolgáló személy jelez, vagy pedig amit a klinikus észlel.

- A kognitív károsodás kimutatható a formális neuropszichológiai vizsgálat során vagy pedig egy globális kognitív teljesítményt felmérő skálán (III. szekcióban részletezett módon).

- A kognitív problémák nem elég súlyosak, hogy a beteg önálló funkcióit korlátozza, azonban a komplex feladatok során némi nehézség előfordulhat.

II. Kizárási kritériumok

- PDD diagnózisa felállítható az MDS-kritériumok alapján [19].

- Kognitív zavart okozó egyéb primer okok jelenléte (például koponyatrauma, stroke, major depresszió, metabolikus eltérések, gyógyszermellékhatások).

- Komorbid állapotok (súlyos depresszió, szorongás, pszichotikus tünetek), amelyek a klinikus megítélése alapján a kognitív vizsgálatot befolyásolja.

III. Specifikus irányelvek az 1. és 2. szintü vizsgálathoz

- Első szintü (Level 1) diagnózis (rövidített értékelés):

- globális kognitív teljesítményt mérő, Parkinson-kóros betegcsoporton validált neuropszichológiai skálán mért csökkent teljesítmény, vagy

- legalább 2 teszten mért csökkent teljesítmény abban az esetben, ha limitált számú tesztbatéria áll rendelkezésre (például a batéria kevesebb, mint két tesztet tartalmaz az öt fó kognitív domén mérésére, vagy kevesebb, mint öt kognitív domént mér).

- Második szintü (Level 2 ) diagnózis (átfogó értékelés):

- Neuropszichológiai tesztfelvétel, amely legalább két tesztet tartalmaz az öt kognitív funkcióra vonatkozóan (figyelem és munkamemória, végrehajtó funkciók, nyelv, memória és téri-vizuális készségek).

- Legalább két neuropszichológiai teszten mért csökkent teljesítmény (egy kognitív funkciót mérő két teszt esetében, vagy egy teszten mért csökkent teljesítmény két kognitív domén esetében).

- A neuropszichológiai teszteken mért csökkent teljesítmény lehet:

a) 1-2 SD teljesítménybeli eltérés a szükséges normálértéktól, vagy

b) jelentős visszaesés a sorozatos tesztfelvételek esetében, vagy

c) jelentős visszaesés a becsült premorbid szinthez képest.

IV. Altipusra vonatkozó megfigyelések

- Egyetlen kognitív területet érintő PD-MCI.

- Több kognitív területet érintő PD-MCI.

Annak ellenére, hogy a megjelenése óta számos vizsgálat alkalmazta a PD-MCI-kritériumokat, a kritérium- rendszer formális validációja még folyamatban van [23]. Követéses vizsgálatok alapján a PD-MCI a PDD „előszobájának" tekinthető [24], és a korai fázisban észlelhető PD-MCI előrevetíti a PDD kialakulásának esélyét [25]. Azonban a PD-MCI-kritériumokat számos kritika is érte. Többek között a premorbid szinthez viszonyított 1,5 SD-s eltérés vizsgálata pontosabbnak tűnik a PDMCI diagnózisának a felállításában, mint a normatív adatokhoz való viszonyítás [26].

A PD-MCI-kritériumok alapján felértékelődik az adott populációra (országra) vonatkozó normatív adatbázis felállítása.

\section{DSM-5-kritériumok}

A 2013-ban bevezetett DSM kézikönyvben (5. verzió, DSM-5) [27] számos új meghatározást találunk a kognitív zavarokat illetően. Bevezeti a neurokognitív zavar (neurocognitive disorders - NCD) definícióját, amely magában foglal minden olyan betegséget, ahol az alapvető károsodás a kognitív funkciókat érinti. Fontos továbbá, hogy neurokognitív zavarok esetében a definíció szerinti károsodás nem a születés vagy pedig a korai mentális fejlődés óta áll fent, hanem bizonyos fokú romlást mutat a korábbi kognitív múködés szintjéhez képest.

Az NCD-n belül két súlyossági szint került bevezetésre: a major és az enyhe neurokognitív zavar, az előbbi a „demencia”, míg az utóbbi az enyhe kognitív zavar megnevezést váltja fel. Az új nómenklatúra egyik oka a demencia kifejezés stigmatizáló, negatív asszociációkkal társuló jelentésének megszüntetése. Ezzel szemben a neurokognitív zavarnak még nincs stigmatizáló hatása, és szélesebb korkategóriát fed le, beleértve a fiatalabb korosztályt is. Bizonyos esetekben a demencia kifejezés még továbbra is használható maradt, mint például PDD esetében is. A neurokognitív zavar a kogníció hat területét vizsgálja, ideértve az összetett figyelmet, a végrehajtó funkciókat, a memóriát, a nyelvi képességeket, a perceptuális-motoros készségeket és a szociális kogníciót.

A DSM-5 szerint a Parkinson-kórhoz társuló neurokognitív zavart (NCD-PD) két lépésben kell diagnosztizálni: az elsőben detektáljuk, hogy a betegnél enyhe vagy major neurokognitív zavar észlelhető, majd a második lépésben a Parkinson-kórral kapcsolatos ok-okozati viszonyt kell megállapítani.

\section{Major neurokognitív zavar (DSM-5)}

A major neurokognitív zavarra a DSM-5 diagnosztikai kézikönyv alapján az alábbi kritériumok vonatkoznak:

- Bizonyíték áll fenn egy vagy több kognitív területen (összetett figyelem, végrehajtó funkció, tanulás és memória, nyelv, perceptuális motoros vagy szociális kogníció) a korábbi teljesítmény-színvonalhoz képest jelentős kognitív hanyatlással kapcsolatban az alábbiak alapján: 
- A személy vagy megfelelő információval rendelkező hozzátartozó, vagy a klinikus aggodalma a kognitív funkció jelentős csökkenésével kapcsolatban.

- A kognitív teljesítmény jelentős károsodása, lehetőleg standardizált neuropszichológiai tesztek vagy ennek hiányában más kvantifikált klinikai mérőeszköz alapján.

- A kognitív deficitek akadályozzák a mindennapi tevékenységekkel kapcsolatos önállóságot. (Legalább a mindennapi életvitel olyan komplex instrumentális tevékenységei során segítség szükséges, mint például a számlák kifizetése vagy a gyógyszerelés.)

- A kognitív deficitek nem kizárólag delíriummal kapcsolatban jelentkeznek.

- A kognitív deficitek nem magyarázhatók jobban más mentális zavarral (például major depresszív zavarral).

\section{Enyhe neurokognitív zavar (DSM-5)}

- Bizonyíték áll fenn egy vagy több kognitív területen a korábbi teljesítmény-színvonalhoz képest mérsékelt kognitív hanyatlással kapcsolatban az alábbiak szerint: - A személy vagy megfelelő információval rendelkező hozzátartozó, vagy a klinikus aggodalma a kognitív funkció jelentős csökkenésével kapcsolatban.

- A kognitív teljesítmény jelentős károsodása, lehetőleg standardizált neuropszichológiai tesztek vagy ennek hiányában más kvantifikált klinikai mérőeszköz alapján.

- A kognitív deficitek nem akadályozzák a mindennapi tevékenységekkel kapcsolatos önállóságot. (A mindennapi életvitel olyan komplex instrumentális tevékenységei, mint a számlák kifizetése vagy a gyógyszerelés megtartottak, azonban nagyobb erőfeszítés, kompenzátoros stratégia vagy alkalmazkodás válhat szükségessé.)

- A kognitív deficitek nem kizárólag delíriummal kapcsolatban jelentkeznek.

- A kognitív deficitek nem magyarázhatók jobban más mentális zavarral (például major depresszív zavar, szkizofrénia).

A diagnosztika lépéseit tekintve major neurokognitív zavar esetében fontos az önellátási képességek vizsgálata és objektív megítélése. Major NCD esetében ez úgy írható le, hogy a beteg helyett olyan tevékenységeket kell másnak elvégeznie, amit korábban önállóan képes volt elvégezni. Enyhe NCD esetében viszont az önellátás teljes körü, azonban a tevékenységek minősége változik, például néhány tevékenység elvégzése sokkal több időt vesz igénybe a beteg számára, vagy pedig a korábbi állapothoz képest sokkal több figyelmet kell szentelnie bizonyos dolgokra.

\section{Parkinson-kórhoz való kapcsolódás igazolása}

Nem elég, hogy a betegnél a major vagy enyhe NCD jelenlétét diagnosztizáljuk, szükséges annak a Parkinsonkórhoz való kapcsolódását is igazolni.
Valószínű NCD-PD jelenléte, ha az alábbiak közül mindkettő teljesül, míg lehetséges az NCD-PD előfordulása, ha csak az egyik feltétel teljesül:

- Nincs bizonyíték a kevert etiológiával kapcsolatban.

(Nem áll fenn más neurodegeneratív vagy cerebrovascularis betegség, vagy más neurológiai, mentális vagy szisztémás betegség vagy állapot, amely valószínúleg hozzájárulhat a kognitív hanyatláshoz.)

- A Parkinson-kór kialakulása egyértelmúen megelőzi a neurokognitív zavar indulását.

\section{A diagnosztikában alkalmazható szürőtesztek}

A neurokognitív károsodások meghatározásában és a mértékének pontos felmérésében nagy problémának számít a megfelelő szưrőtesztek hiánya. A bemutatásra kerülő tesztek például a legtöbb nyelven még csak az MDS-kritériumrendszer szempontjából kerültek validálásra, az új DSM-5 neurokognitív zavarokra vonatkozó kritériumrendszeréhez való adaptálásuk még várat magára. Az ideális szưrőteszt nem túl hosszú, a tesztfelvétel gyorsan kivitelezhető, és magas szenzitivitás-specificitás mutatókkal rendelkezik a kognitív zavarok minden fajtájának pontos meghatározásához.

\section{Mini-Mentál Státus Vizsgálat}

Magyarországon a Mini-Mentál Státus Vizsgálat (MiniMental State Examination - MMSE) számít a legelterjedtebbnek a kognitív készségek felmérését illetően [28]. A demencia kezelésére alkalmazott gyógyszerek rendelhetôségét is az Országos Egészségbiztosítási Pénztár az MMSE-vizsgálaton elért eredményhez köti.

Habár az MMSE a kogníció olyan területeit is lefedi, mint az orientáció, memória, a vizuális készségek, a figyelem és számolás, a nyelv, az írás/olvasás és a konstrukciós készségek, a téri-vizuális és végrehajtó funkciózavarok detektálásához nem elég szenzitív [29]. Ezen túlmenően a teszt további hátránya, hogy alkalmatlan a kezdeti stádiumban lévő demencia érzékelésére is [30]. Bár számos nyelven validálták és széles körben alkalmazzák, a PDD szűrésére a gyenge tesztmutatói miatt önmagában alkalmatlan [28].

\section{Montreal Kognitív Felmérés}

A Montreal Kognitív Felmérést (Montreal Cognitive Assessment - MoCA) nemcsak az Alzheimer-demencia, hanem az MCI felismerésére is alkalmas [31]. A tesztfelvétel hozzávetőlegesen 10 percet igényel, ami akár a betegágy mellett is kivitelezhető. A teszt a kognitív funkciók hét területét méri: téri/exekutív funkciók, megnevezés, memória, figyelem, nyelv, absztrakció és orientáció. Az MMSE-hez viszonyítva a MoCA érzékenyebben méri fel az esetleges exekutív vagy vizuális-térbeli és figyelmi zavarokat, amelyek a kogníció leggyakrabban károsodott területeinek számítanak PD esetében. A MoCA-teszt előnyei között említhető, hogy ma már széles körben használt és több idegen nyelvű fordítással rendelkezik [32]. 
A MoCA inter-rater és teszt-reteszt megbízhatósága magas, illetve jó diszkriminatív tulajdonságokkal rendelkezik PDD [33] és PD-MCI esetében [34, 35]. A MoCA alkalmas a betegek neurokognitív teljesítményváltozásának nyomon követésére is, mivel több alternatív változattal is rendelkezik. A Parkinson Study Group például a MoCA-teszt alkalmazását ajánlja azon vizsgálatok esetében, amelyeknél nem a kognitív teljesítményváltozás az elsődleges végpont [29].

Annak ellenére, hogy a MoCA- és az MMSE-értékek egymással konvertálhatók [36], gyakran találhatunk olyan leleteket, amelyekben az MMSE még normáltartományt mutat, de a MoCA már neurokognitív zavart jelez. Ezen betegeknél a részletes neuropszichológiai, illetve képalkotó vizsgálatok már enyhébb fokú neurokognitív és strukturális károsodásokat mutatnak [37]. A fenti kedvező adatok ellenére, az MDS Task Force által végzett vizsgálatok alapján, a MoCA önmagában még nem elég specifikus a PD-MCI detektálására [38].

\section{Addenbrooke Kognitív Vizsgálat}

Magyarországon szintén használatos szűrőteszt az Addenbrooke Kognitív Vizsgálat (Addenbrooke's Cognitive Examination - ACE). Annak ellenére, hogy az ACE-t eredetileg Alzheimer-demencia detektálására fejlesztették ki, a PDD-hez kapcsolható föbb kognitív területeket is méri (orientáció, figyelem, mentális flexibilitás, epizodikus és szemantikus memória, verbális fluencia, afázia, valamint a téri-vizuális és konstrukciós képességek). Alkalmas a korai demencia és annak néhány altípusának detektálására, viszont Parkinson-kór esetében limitált adat áll rendelkezésre az alkalmazhatóságával kapcsolatban. Az ACE-tesztet körültekintően kell használnunk a PD-MCI diagnosztikájában, ugyanis a teszteredményt jelentősen befolyásolja a verbális fluencia alskálán elért pontszám, valamint a vizsgált személy iskolázottsága is [28].

$\mathrm{Az}$ eredeti ACE kevésbé szenzitív részeinek átdolgozásával készült el az ACE-R (Addenbrooke's Cognitive Examination-Revised). Az ACE-R a PD-MCI detektálására elfogadható diagnosztikai pontossággal képes $(<89$ határpont, szenzitivitás: 69\%, specificitás: 84\%) [39]. Az ACE legújabb verzióját (ACE-III) 2012-ben fejlesztették ki. Az ACE-III jelen közlemény szerzői által elkészített magyar nyelvi validált verziója a https://lodestone. neura.edu.au/frontier/ace-iii/ oldalról tölthető le és díjmentesen használható. Az ACE-III PDD és PD-MCIben történő validálása folyamatban van.

Az ACE-III kérdésein alapuló rövidített szűrőtesztet 2014-ben fejlesztették ki Mini-ACE (M-ACE) néven, amelynek magyar nyelvi validált verziója is elérhető a fent említett honlapról. Amennyiben a PD-ben végzett validációs vizsgálatok eredményesen zárulnak, úgy az M-ACE megbízható skála lehet a neurokognitív zavarra vonatkozó szûróvizsgálatokban.

\section{Mattis Demencia Pontozó Skála}

A Mattis Demencia Pontozó Skála (MDRS) széles körben használt neurokognitív szürőtesztként ismert. A teszt alskálái a kogníció nagy spektrumát lefedi: figyelem, iniciáció és perszeveráció, konstrukció, konceptualizáció és memória. A teszt szenzitívnek mondható a mediotemporalis és frontalis patológiákra [40], az európai DBSközpontokban gyakran használt szürőtesztként kerül alkalmazásra [2, 41, 42]. Az elérhető maximális pontszám 144 pont. A szúrôteszt hátránya viszont az, hogy a fentebb említett szûrőeszközökhöz képest a tesztfelvétel ideje jóval hosszabb, a tünetek súlyosságától függően körülbelül 30-45 percet vesz igénybe, ezért a teszt alkalmazása nem minden esetben számít a legmegfelelőbb megoldásnak PDD-diagnosztika esetében.

\section{Magyar normatín adatok}

A Pécsi Tudományegyetem, Neurológiai Klinikán gondozott PD-betegek bevonásával célul tûztük ki a klinikai gyakorlatban leggyakrabban alkalmazott neurokognitív szûrőtesztek DSM-5 szerinti magyar populáción végzett validációját. Az ETT-TUKEB által 30102/2012/EKU számon engedélyezett, majd 14437/2013/EKU számon módosított, illetve a PTE Regionális és Intézményi Kutatás-Etikai Bizottsága által 4678-as számon elfogadott protokoll alapján a PTE Neurológiai Klinikán 350 beteg került bevonásra. A neurokognitív státus felmérése (MMSE, MoCA, ACE és MDRS) mellett a depresszív tünetek mérését is elvégeztük a Montgomery-Asberg Depresszió Pontozó Skála alkalmazásával [28]. A betegeket az iskolázottság mértéke alapján három kategóriába soroltuk: alacsony iskolázottság (0-8 év), közepes fokú iskolázottság (9-12 év) és magas iskolázottság ( $\geq 13$ év). A betegek neurokognitív státusának besorolása a DSM-5 alapján történt. Mivel a súlyos depresszív tünetek negatívan befolyásolhatják a kognitív teljesítményt, a normatív adatok meghatározásából kizártuk azokat a betegeket, akik a Montgomery-Asberg Depresszió Pontozó Skálán > 18 pontot értek el. A normatív adatok kiértékeléséhez az R Project for Statistical Computing (Windows verzió, 3.1.2) programcsomagot használtuk. Az egyes tesztekhez használható határértéket ROC-analízis segítségével határoztuk meg. Azt a határértéket választottuk, amelynek specificitás- és szenzitivitásértéke a legközelebb helyezkedett el az (1,0) koordinátaponthoz.

A normatív adatok kiértékeléséhez 295, nem depreszsziós, klinikailag Parkinson-kóros beteg eredményeit dolgoztuk fel. Részletes neuropszichológiai felmérés alapján $52(17,6 \%)$ esetben enyhe NCD-PD és 42 (14,2\%) esetben major NCD-PD volt diagnosztizálható. A normatív adatokat az 1 . táblázatban mutatjuk be, míg a főbb szúrótesztek határértékeit, illetve specificitás- és szenzitivitásmutatóit a 2. táblázatban. 


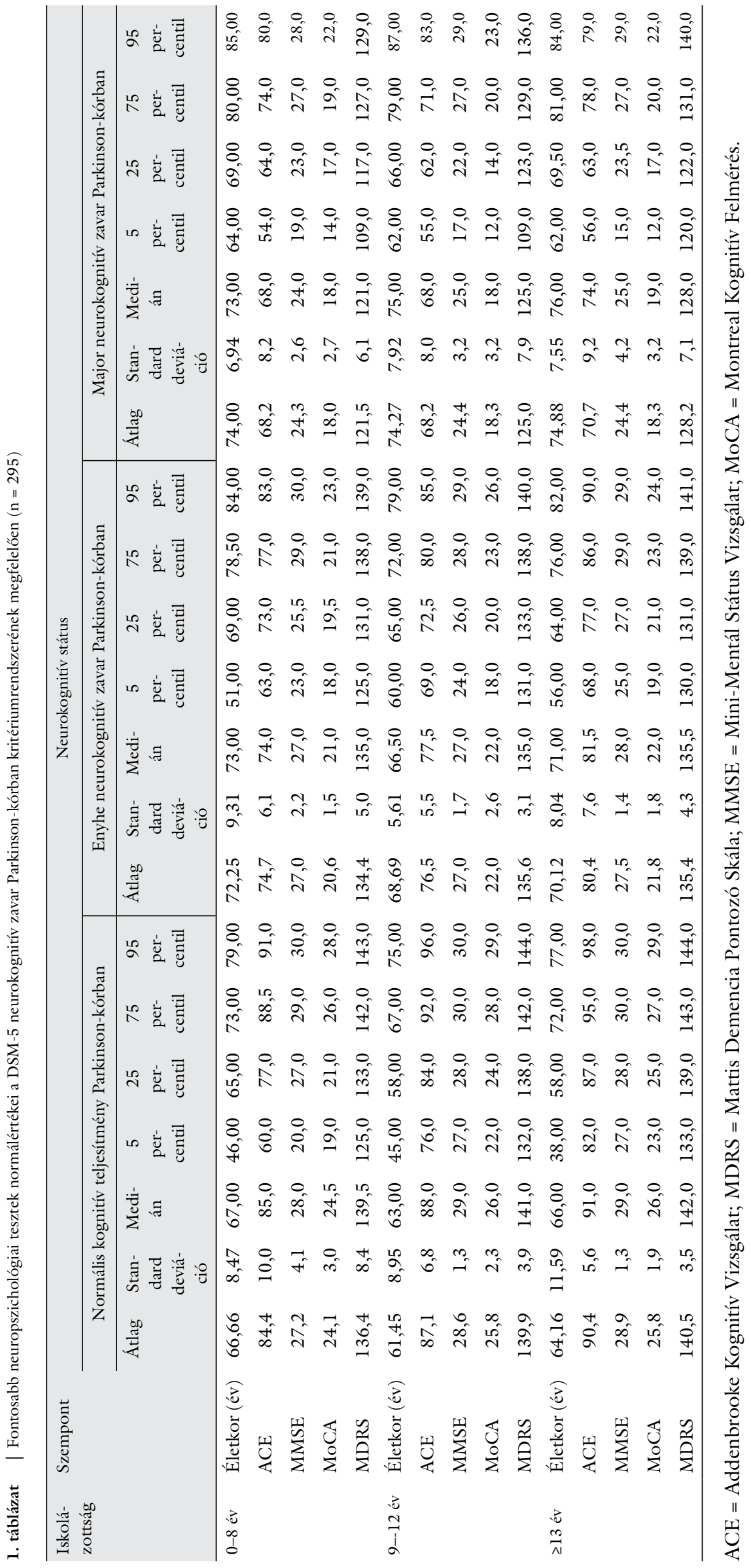


2. táblázat | Fontosabb neuropszichológiai tesztek határértékei a DSM-5 szerinti enyhe és major neurokognitív zavar Parkinson-kórban szűréséhez

\begin{tabular}{llccc|ccc}
\hline Iskolázottság & Teszt & \multicolumn{2}{c|}{ Enyhe neurokognitív zavar Parkinson-kórban } & \multicolumn{3}{c}{ Major neurokognitív zavar Parkinson-kórban } \\
\cline { 3 - 8 } & & Határpont & Szenzitivitás & Specificitás & Határpont & Szenzitivitás & Specificitás \\
\hline $0-8$ év & ACE & 82,5 & 0,989 & 0,542 & 78,5 & 0,913 & 0,792 \\
& MMSE & 26,5 & 0,333 & 0,958 & 26,5 & 0,696 & 0,958 \\
& MoCA & 23,5 & 0,979 & 0,667 & 20,5 & 0,957 & 0,875 \\
& MDRS & 138,5 & 0,982 & 0,542 & 128,5 & 0,870 & 0,833 \\
\multirow{3}{*}{$9-12$ év } & ACE & 83,5 & 0,913 & 0,813 & 80,5 & 0,909 & 0,888 \\
& MMSE & 27,5 & 0,565 & 0,863 & 27,5 & 0,818 & 0,863 \\
& MoCA & 24,5 & 0,870 & 0,713 & 21,5 & 0,909 & 0,950 \\
& MDRS & 139,5 & 0,957 & 0,713 & 130,5 & 0,954 & 0,988 \\
& ACE & 84,5 & 0,714 & 0,893 & 81,5 & 0,833 & 0,961 \\
& MMSE & 28,5 & 0,714 & 0,738 & 27,5 & 0,753 & 0,864 \\
& MoCA & 24,5 & 0,952 & 0,903 & 21,5 & 0,833 & 0,971 \\
& MDRS & 139,5 & 0,905 & 0,738 & 131,5 & 0,843 & 0,990 \\
\hline
\end{tabular}

ACE = Addenbrooke Kognitív Vizsgálat; MDRS = Mattis Demencia Pontozó Skála; MMSE = Mini-Mentál Státus Vizsgálat; MoCA = Montreal Kognitív Felmérés.

A MoCA-teszt esetében a magyar populációban az Alzheimer-típusú MCI detektálására a 24 értékponthatár rendelkezik a legjobb diszkriminatív erővel [32]. A DSM-5 szerinti Parkinson-kórhoz társuló minor és major neurokognitív zavar elkülönítéséhez a 23,5-24,5 és a 20,5-21,5 ponthatárok tűnnek a legmegbízhatóbbnak a vizsgált személy iskolázottságától függő́n (2. táblázat).

Az ACE esetében az enyhe NCD-PD-re vonatkozó határértékek 82,5-84,5, míg a major NCD-PD-re vonatkozó értékek 78,5-81,5 pont között változnak az edukáció szintjétől függően.

Az MDRS-re vonatkozó nemzetközi vizsgálatok szerint a PD-MCI 138-140 közötti határértékekkel azonosítható $[43,44,45]$, míg a PDD 123-132 ponttal [28, $44,45]$. A magyar PD-populáción meghatározott vágóértékek is ebbe a tartományba esnek: 138,5-139,5, illetve $128,5-131,5$ az iskolázottságtól függően (2. táblázat).

\section{Neurokognitív zavarok kezelési lehetőségei}

A Parkinson-kórhoz társuló demencia vagy enyhe neurokognitív zavar időben történő felismerésének és kezelésének elsődleges szempontja a beteg önálló életvitelre való képességének megőrzése. Fontos, hogy megfelelő biztonságérzetet biztosítsunk a beteg számára a mindennapi feladatainak ellátásában, mint például az autóvezetés, a biztonságos közlekedés vagy a háztartási munkák elvégzése. Az enyhe neurokognitív zavar korai diagnosztizálása nemcsak a demencia várható megjelenését jelzi előre, hanem a családtagok, gondozók számára is lehetőséget ad felkészülni az esetlegesen megjelenő problémák kezelésére. Lehetőség nyílik továbbá a megfelelő kezelés kiválasztására, amelynek köszönhetően az esetleges betegotthonba való költöztetés szükségessége időben kitolható.

\section{Gyógyszeres kezelés}

A minor NCD kezelésére törzskönyvezett gyógyszer jelenleg nem áll rendelkezésünkre. A mediterrán étrend, a rendszeres szociális és mentális feladatok, illetve tevékenységek elvégzése, a rendszeres fizikai aktivitás csökkentheti a minor NCD major NCD-be való átalakulását $[46,47,48,49]$. A nem specifikus gyógyszeres kezelés a motoros és nem motoros tünetek - úgymint az alvászavar, a gastrointestinalis problémák és depresszió - kezelése köré összpontosul, mivel ezen tünetek megléte gyakorolja a legnagyobb hatást a beteg életminőségére [50]. A depresszió és a szorongás tüneti kezelése jótékony lehet a figyelmi funkciókra, ami a beteg életvitelére is kedvező hatással lehet [50].

A már kialakult PDD esetében a fent említett aspecifikus kezelések mellett hatásos lehet a kolinészterázgátló, illetve az NMDA-antagonista memantin [51] alkalmazása. A Cochrane adatbázis alapján a kolinészterázgátlók hatékonyak a PDD kezelésében [52]. A kolinészterázgátlók a kolinerg rendszerben fellépó károsodás ellensúlyozásával képesek lassítani a kognitív teljesítményromlást, valamint enyhe-közepes stádiumban az információfeldolgozás képességét. A kognitív teljesítmény javítása révén az életvitelre is kedvező hatást gyakorolnak. A kolinészterázgátlók közül a rivastigmin nemcsak a neurokognitív zavar tüneteinek a kezelésére alkalmas, hanem enyhíti az apátiát is. Ezen apátiajavító hatás PDD-ben a nem depressziós, nem demens betegek 
esetében is kimutatható [53]. Feltételezhető, hogy a kolinészterázgátló kezelésben részesülők esetében az NCD progressziója lassabb, mint a placebokezelésben részesülő betegeknél. A kolinészterázgátlók javítják a járulékos tünetek - úgymint agitáció, elkóborlás és a szociálisan nem megfelelő viselkedés - előfordulását is. A Magyarországon elérhető rivastigmin és donepezil hasonló mellékhatásprofillal rendelkezik: Leggyakrabban hányinger, hányás, hasmenés, szédülékenység jelentkezhet, amely lassú feltitrálás vagy transdermalis tapasz formájában történő alkalmazás esetén részben elkerülhető. Mivel bradycardiát okozhatnak, a kollapszushoz társuló elesés és következményes combnyaktörés elkerüléséhez az óvatos feltitrálás és a hozzátartozók felvilágosítása is szükséges.

Enyhe-közepes demencia esetében a kolinészterázgátlók, a súlyos fokú demencia esetében a memantin és a nagy dózisú rivastigmin $(13,3 \mathrm{mg})$ rendelkezik törzskönyvi indikációval.

\section{Nem gyógyszeres kezelés}

A hatékonyabb kezelés érdekében a gyógyszeres kezelés mellett a strukturált kognitív rehabilitációs tréningprogramok lehetőségeit is célszerü igénybe venni [54]. A Parkinson-kóros betegek figyelemre, absztrakt gondolkodásra, téri-vizuális funkciókra fokuszáló kognitív tréning pozitív hatású a kogníció azon aspektusaira is, amelyek a frontális múködéstől függenek [50]. Az eredmények tükrében elmondható, hogy a személyre szabott vagy az adott neurodegeneratív megbetegedés jellegzetes tüneteihez igazított kognitív tréning nagyban hozzájárulhat a betegek életminőségének javításához [55]. A kognitív tréning bizonyos fokú pozitív hatást gyakorol a memóriafunkciókra, az életvitelre és az életminőségre is [56, $57,58]$.

\section{Következtetések}

Közleményünkben részletesen bemutattuk a Parkinsonkórhoz társuló neurokognitív zavarok jellegzetességeit, felmérésük lehetséges módjait és kezelési lehetőségeit. A neurokognitív zavarok felmérését és meghatározását sokáig nehezítette a diagnosztikai kritériumrendszerek sokszínűsége. A DSM-5 major és enyhe neurokognitív zavarra vonatkozó definíciói a klinikumban jól alkalmazhatóak, ám szükségessé vált a leggyakrabban használt szürőtesztek, mint az MMSE, az ACE, a MoCA és az MDRS új kritériumrendszerhez való validálása. Az MDS szerinti PD-MCI diagnózisának felállításához fontos ismerni és alkalmazni a magyar populációra vonatkozó normatív adatokat, míg a DSM-5 szerinti NCD-PD diagnózisának felállításához a szűrőteszteken alkalmazható határértékeket meghatározni. A neurokognitív zavarok időben történő diagnosztizálása és korai kezelése fontos a jó életminőség fenntarthatósága érdekében, a tüneti kontroll, illetve a betegség progressziójának lassítása érdekében is.
Anyagi támogatás: A vizsgálat kivitelezését a Bolyai János Kutatási Ösztöndíj, a Nemzeti Agykutatási Program - KTIA_13_NAP-AII/10. nyilvántartási számú pályázata, az OTKA PD103964 és OTKA 106176 támogatta.

Szerzői munkamegosztás: L. T., K. K., K. N.: Tervezés, kivitelezés, kiértékelés, kézirat elkészítése. K. S., J. J., K. J., M. A., K. M., W. R., D. G., A. Zs.: Kivitelezés, kézirat áttekintése. A cikk végleges változatát valamennyi szerző elolvasta és jóváhagyta.

Érdekeltségek: A szerzőknek nincsenek érdekeltségeik.

\section{Irodalom}

[1] Leroi, I., McDonald, K., Pantula, H., et al.: Cognitive impairment in Parkinson disease: impact on quality of life, disability, and caregiver burden. J. Geriatr. Psychiatry Neurol., 2012, 25(4), 208-214.

[2] Kovács, N.: Parkinson's disease from the perspective of general practice. [A Parkinson-kór a gyakorló orvosok szemszögéből.] Lege Artis Medicinae, 2014, 24(8-9), 406-414. [Hungarian]

[3] Yarnall, A. J., Breen, D. P., Duncan, G. W., et al.: Characterizing mild cognitive impairment in incident Parkinson disease: the ICICLE-PD study. Neurology, 2014, 82(4), 308-316.

[4] Pfeiffer, H. C., Løkkegaard, A., Zoetmulder, M., et al.: Cognitive impairment in early-stage non-demented Parkinson's disease patients. Acta Neurol. Scand., 2014, 129(5), 307-318.

[5] Halliday, G. M., Leverenz, J. B., Schneider, J. S., et al.: The neurobiological basis of cognitive impairment in Parkinson's disease. Mov. Disord., 2014, 29(5), 634-650.

[6] Poletti, M., Emre, M., Bonuccelli, U.: Mild cognitive impairment and cognitive reserve in Parkinson's disease. Parkinsonism Relat. Disord., 2011, 17(8), 579-586.

[7] Godefroy, O., Azouvi, P., Robert, P., et al.: Dysexecutive syndrome: diagnostic criteria and validation study. Ann. Neurol., 2010, 68(6), 855-864.

[8] Karádi, K., Lucza, T., Aschermann, Z., et al.: Visuospatial impairment in Parkinson's disease: the role of laterality. Laterality, $2015,20(1), 112-127$.

[9] Sanyal, J., Banerjee, T. K., Rao, V. R.: Dementia and cognitive impairment in patients with Parkinson's disease from India: a 7-year prospective study. Am. J. Alzheimers Dis. Other Demen., $2014,29(7), 630-636$.

[10] Reid, W. G., Hely, M. A., Morris, J. G., et al.: Dementia in Parkinson's disease: a 20-year neuropsychological study (Sydney Multicentre Study). J. Neurol. Neurosurg. Psychiatry, 2011, 82(9), 1033-1037.

[11] Balzer-Geldsetzer, M., Costa, A. S., Kronenbürger, M., et al.: Parkinson's disease and dementia: a longitudinal study (DEMPARK). Neuroepidemiology, 2011, 37(3-4), 168-176.

[12] Marder, K.: Cognitive impairment and dementia in Parkinson's disease. Mov. Disord., 2010, 25(Suppl. 1), S110-S116.

[13] Aarsland, D., Andersen, K., Larsen, J. P., et al.: Prevalence and characteristics of dementia in Parkinson disease: an 8-year prospective study. Arch. Neurol., 2003, 60(3), 387-392.

[14] Martínez-Horta, S., Kulisevsky, J.: Is all cognitive impairment in Parkinson's disease "mild cognitive impairment"? J. Neural. Transm., 2011, 118(8), 1185-1190.

[15] Janvin, C. C., Larsen, J. P., Aarsland, D., et al.: Subtypes of mild cognitive impairment in Parkinson's disease: progression to dementia. Mov. Disord., 2006, 21(9), 1343-1349.

[16] Palavra, N. C., Naismith, S. L., Lewis, S. J.: Mild cognitive impairment in Parkinson's disease: a review of current concepts. Neurol. Res. Int., 2013, 2013, 576091. 
[17] Kovács, N., Balás, I., Llumiguano, C., et al.: Deep brain stimulation: a novel possibility for the treatment of movement disorders. [Mély agyi stimuláció: új perspektíva a mozgászavarok kezelésében.] Lege Artis Medicinae, 2009, 19(2), 119-126. [Hungarian]

[18] American Psychiatric Association: Diagnostic and statistical manual of mental disorders. American Psychiatric Publishing, Washington, 2000.

[19] Emre, M., Aarsland, D., Brown, R., et al.: Clinical diagnostic criteria for dementia associated with Parkinson's disease. Mov. Disord., 2007, 22(12), 1689-1707.

[20] Dubois, B., Burn, D., Goetz, C., et al.: Diagnostic procedures for Parkinson's disease dementia: recommendations from the Movement Disorder Society Task Force. Mov. Disord., 2007, 22(16), 2314-2324.

[21] Litvan, I., Goldman, J. G., Tröster, A. I., et al.: Diagnostic criteria for mild cognitive impairment in Parkinson's disease: Movement Disorder Society Task Force guidelines. Mov. Disord., 2012, 27(3), 349-356.

[22] Martinez-Martin, P., Falup-Pecurariu, C., Rodriguez-Blazquez, C., et al.: Dementia associated with Parkinson's disease: applying the Movement Disorder Society Task Force criteria. Parkinsonism Relat. Disord., 2011, 17(8), 621-624.

[23] Geurtsen, G. J., Hoogland, J., Goldman, J. G., et al.: Parkinson's disease mild cognitive impairment: application and validation of the criteria. J. Parkinsons Dis., 2014, 4(2), 131-137.

[24] Hobson, P., Meara, J.: Mild cognitive impairment in Parkinson's disease and its progression onto dementia: a 16-year outcome evaluation of the Denbighshire cohort. Int. J. Geriatr. Psychiatry, $2015 \mathrm{Feb} 11$. [Epub ahead of print]

[25] Domellöf, M. E., Ekman, U., Forsgren, L., et al.: Cognitive function in the early phase of Parkinson's disease, a five-year followup. Acta Neurol. Scand., 2015 Feb 3. [Epub ahead of print]

[26] Szeto, J. Y., Mowszowski, L., Gilat, M., et al.: Assessing the utility of the Movement Disorder Society Task Force Level 1 diagnostic criteria for mild cognitive impairment in Parkinson's disease. Parkinsonism Relat. Disord., 2015, 21(1), 31-35.

[27] American Psychiatric Association: Diagnostic and statistical manual of mental disorders. American Psychiatric Publishing, Arlington, 2013

[28] Kaszás, B., Kovács, N., Balás, I., et al.: Sensitivity and specificity of Addenbrooke's Cognitive Examination, Mattis Dementia Rating Scale, Frontal Assessment Battery and Mini Mental State Examination for diagnosing dementia in Parkinson's disease. Parkinsonism Relat. Disord., 2012, 18(5), 553-556.

[29] Chou, K. L., Amick, M. M., Brandt, J., et al.: A recommended scale for cognitive screening in clinical trials of Parkinson's disease. Mov. Disord., 2010, 25(15), 2501-2507.

[30] Feher, E. P., Mahurin, R. K., Doody, R. S., et al.: Establishing the limits of the Mini-Mental State. Examination of 'subtests'. Arch. Neurol., 1992, 49(1), 87-92.

[31] Nasreddine, Z. S., Phillips, N. A., Bédirian, V., et al.: The Montreal Cognitive Assessment, MoCA: a brief screening tool for mild cognitive impairment. J. Am. Geriatr. Soc., 2005, 53(4), 695-699

[32] Volosin, M., Janacsek, K., Németh, D.: Hungarian version of the Montreal Cognitive Assessment (MoCA) for screening mild cognitive impairment. [A Montreal Kognitiv Felmérés (MoCA) magyar nyelvú adaptálása egészséges, enyhe kognitiv zavarban és demenciában szenvedő idős személyek körében.] Psychiatr. Hung., 2013, 28(4), 370-392. [Hungarian]

[33] Gill, D. J., Freshman, A., Blender, J. A., et al.: The Montreal cognitive assessment as a screening tool for cognitive impairment in Parkinson's disease. Mov. Disord., 2008, 23(7), 1043-1046.

[34] Kandiah, N., Zhang, A., Cenina, A. R., et al.: Montreal Cognitive Assessment for the screening and prediction of cognitive decline in early Parkinson's disease. Parkinsonism Relat. Disord., 2014, 20(11), 1145-1148.
[35] Dalrymple-Alford, J. C., MacAskill, M. R., Nakas, C. T., et al.: The MoCA: well-suited screen for cognitive impairment in Parkinson disease. Neurology, 2010, 75(19), 1717-1725.

[36] Van Steenoven, I., Aarsland, D., Hurtig, H., et al.: Conversion between Mini-Mental State Examination, Montreal Cognitive Assessment, and Dementia Rating Scale-2 scores in Parkinson's disease. Mov. Disord., 2014, 29(14), 1809-1815.

[37] Chou, K. L., Lenhart, A., Koeppe, R. A., et al.: Abnormal MoCA and normal range MMSE scores in Parkinson disease without dementia: cognitive and neurochemical correlates. Parkinsonism Relat. Disord., 2014, 20(10), 1076-1080.

[38] Marras, C., Armstrong, M. J., Meaney, C. A., et al.: Measuring mild cognitive impairment in patients with Parkinson's disease. Mov. Disord., 2013, 28(5), 626-633.

[39] McColgan, P., Evans, J. R., Breen, D. P., et al.: Addenbrooke's Cognitive Examination-Revised for mild cognitive impairment in Parkinson's disease. Mov. Disord., 2012, 27(9), 1173-1177.

[40] Brown, G. G., Rabill, A. A., Gorell, J. M., et al.: Validity of the Dementia Rating Scale in assessing cognitive function in Parkinson's disease. J. Geriatr. Psychiatry Neurol., 1999, 12(4), 180188.

[41] Fehér, G., Balás, I., Komoly, S., et al.: Effectiveness of bilateral subthalamic stimulation in the mirror of changes in drug treatment of Parkinson's disease. [A kétoldali subthalamicus stimuláció hatékonysága az antiparkinson gyógyszerelés változtatásának tükrében.] Ideggyogy. Sz., 2010, 63(9-10), 314-319. [Hungarian]

[42] Kovács, N., Aschermann, Zs., Nagy, F., et al.: Role of deep brain stimulation in the treatment of movement disorders. [Mély agyi stimuláció szerepe a mozgászavarok kezelésében.] Magy. Orv., 2011, 19(7-8), 32-34. [Hungarian]

[43] Pirogovsky, E., Schiehser, D. M., Litvan, I., et al.: The utility of the Mattis Dementia Rating Scale in Parkinson's disease mild cognitive impairment. Parkinsonism Relat. Disord., 2014, 20(6), 627631.

[44] Matteau, E., Dupré, N., Langlois, M., et al.: Clinical validity of the Mattis Dementia Rating Scale-2 in Parkinson disease with MCI and dementia. J. Geriatr. Psychiatry Neurol., 2012, 25(2), $100-106$.

[45] Villeneuve, S., Rodrigues-Brazète, J., Joncas, S., et al.: Validity of the Mattis Dementia Rating Scale to detect mild cognitive impairment in Parkinson's disease and REM sleep behavior disorder. Dement. Geriatr. Cogn. Disord., 2011, 31(3), 210-217.

[46] Schlosser Covell, G. E., Hoffman-Snyder, C. R., Wellik, K. E., et al.: Physical activity level and future risk of mild cognitive impairment or dementia: a critically appraised topic. Neurologist, 2015, 19(3), 89-91.

[47] Scarmeas, N., Luchsinger, J. A., Brickman, A. M., et al.: Physical activity and Alzheimer disease course. Am. J. Geriatr. Psychiatry, $2011,19(5), 471-481$

[48] Grande, G., Vanacore, N., Maggiore, L., et al.: Physical activity reduces the risk of dementia in mild cognitive impairment subjects: a cohort study. J. Alzheimers Dis., 2014, 39(4), 833-839.

[49] Aarsland, D., Laake, K., Larsen, J. P., et al.: Donepezil for cognitive impairment in Parkinson's disease: a randomised controlled study. J. Neurol. Neurosurg. Psychiatry, 2002, 72(6), 708-712.

[50] Kehagia, A. A., Barker, R. A., Robbins, T. W.: Neuropsychological and clinical heterogeneity of cognitive impairment and dementia in patients with Parkinson's disease. Lancet Neurol., 2010, 9(12), 1200-1213.

[51] Larsson, V., Engedal, K., Aarsland, D., et al.: Quality of life and the effect of memantine in dementia with lewy bodies and Parkinson's disease dementia. Dement. Geriatr. Cogn. Disord., 2011, 32(4), 227-234.

[52] Rolinski, M., Fox, C., Maidment, I., et al.: Cholinesterase inhibitors for dementia with Lewy bodies, Parkinson's disease dementia and cognitive impairment in Parkinson's disease. Cochrane Database Syst. Rev., 2012, 3, CD006504. 
[53] Devos, D., Moreau, C., Maltête, D., et al.: Rivastigmine in apathetic but dementia and depression-free patients with Parkinson's disease: a double-blind, placebo-controlled, randomised clinical trial. J. Neurol. Neurosurg. Psychiatry, 2014, 85(6), 668-674.

[54] Kincses, P., Kovács, N., Karádi, K., et al.: Critical issues of the biopsychosocial treatment of Parkinson's disease. [A Parkinsonkór biopszichoszociális ellátásának kritikus kérdései.] Orv. Hetil., 2015, 156(12), 472-478. [Hungarian]

[55] Langenbahn, D. M., Ashman, T., Cantor, J., et al.: An evidencebased review of cognitive rehabilitation in medical conditions affecting cognitive function. Arch. Phys. Med. Rehabil., 2013, 94(2), 271-286.

[56] Cerasa, A., Quattrone, A.: The effectiveness of cognitive treatment in patients with Parkinson's disease: a new phase for the neuropsychological rehabilitation. Parkinsonism Relat. Disord., 2015, 21(2), 165.

[57] Reuter, I., Mehnert, S., Sammer, G., et al.: Efficacy of a multimodal cognitive rehabilitation including psychomotor and endurance training in Parkinson's disease. J. Aging Res., 2012, 2012, 235765

[58] Kalbe, E., Kessler, J.: Task force WANTED: Many reasons to promote research on cognitive rehabilitation to prevent, delay, and treat cognitive dysfunctions in patients with Parkinson's disease. Parkinsonism Relat. Disord., 2015, 21(2), 166-167.

(Kovács Norbert dr., Pécs, Rét utca 2., 7623 e-mail: norbert.kovacs@aok.pte.hu)

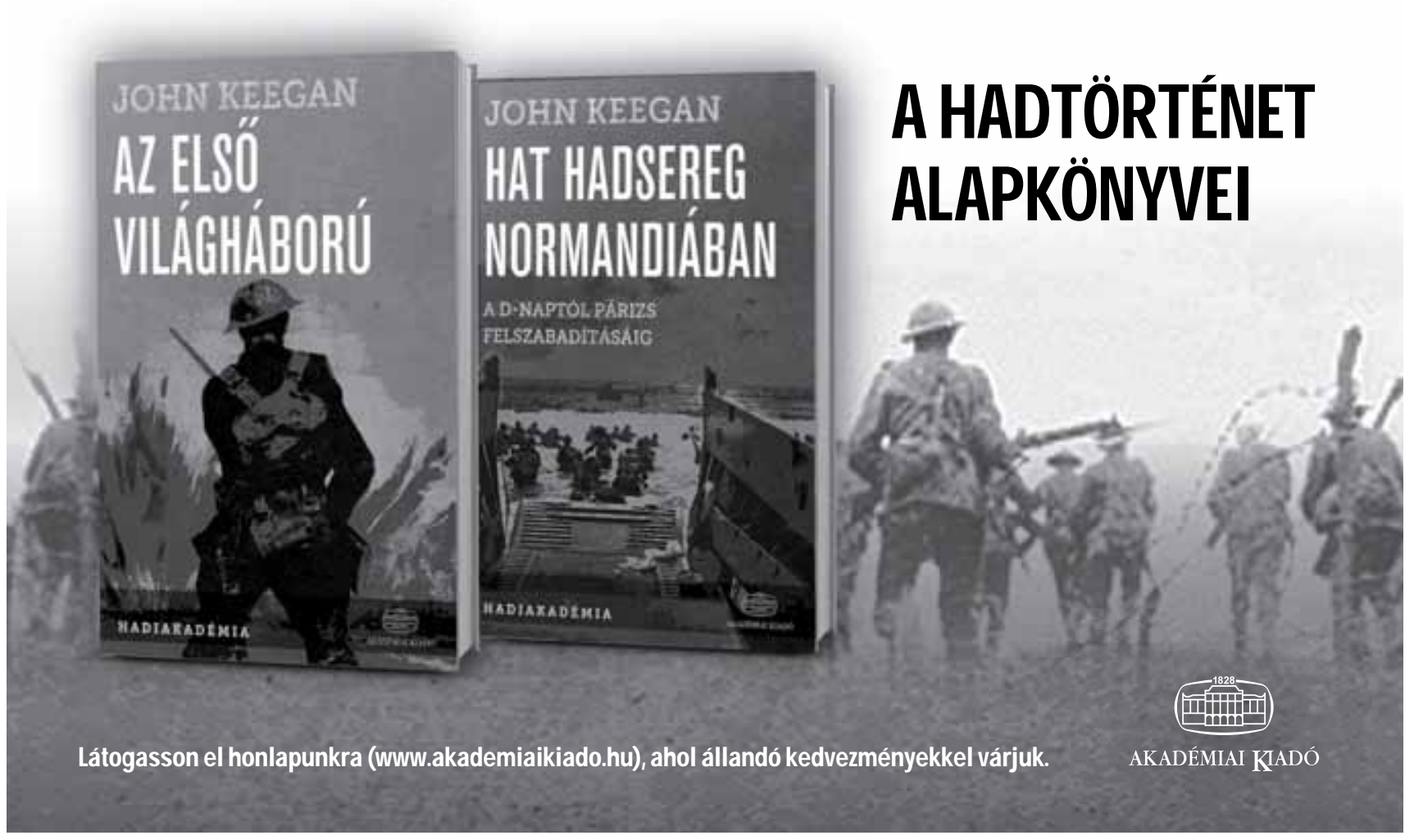

